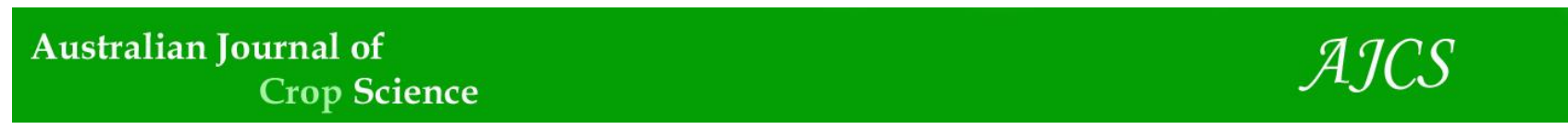

AJCS 12(03):472-477 (2018)

ISSN:1835-2707

doi: 10.21475/ajcs.18.12.03.pne966

\title{
Selectivity and efficacy of herbicides to control volunteer soybean in castor crop
}

\author{
Isabela Pimentel de Almeida ${ }^{1}$, Augusto Guerreiro Fontoura Costa ${ }^{2 *}$, Valdinei Sofiatti ${ }^{2}$, Cleber Daniel de \\ Goes Maciel ${ }^{3}$
}

${ }^{1}$ Universidade Estadual da Paraíba (UEPB). R. Baraúnas, 351, Campina Grande, PB, Zip code: 58429-500, Brazil

${ }^{2}$ Empresa Brasileira de Pesquisa Agropecuária-Embrapa Algodão, Rua Oswaldo Cruz, 1143. Campina Grande, PB, Zip code: 58428-095, Brazil

${ }^{3}$ Universidade do Centro-Oeste (Unicentro). R. Simeão Camargo de Varela Sá, 03. Guarapuava, PR, Zip code: $85040-$ 080, Brazil

*Corresponding author: augusto.costa@embrapa.br

\begin{abstract}
Castor bean is an alternative to many grain production areas, mainly as crop for the second season after soybean. In this scenario, there is demand for research on management of plants, resulting from remaining seeds of soybean after harvest. The objective of this work was to evaluate the selectivity and efficacy of post-emergence herbicides for the control of volunteer soybean in the castor crop. Two greenhouse experiments were carried out in a completely randomized design with four replications. The first assay was focused on the selectivity of herbicides to the castor crop, and the second to the efficacy of herbicides for soybean control. Evaluation of herbicide selectivity for the castor cultivar BRS Energia was carried out at 4 to 6 true leave stages. The treatments corresponded to two doses of ethoxysulfuron, halosulfuron-methyl, iodosulfuron-methyl, ioxynil, metamitron, oxadiazon and a control without any application. To evaluate the control efficacy of soybean cultivar BRS 3280RR in 3 trefoil stage, the treatments were comprised of two doses of ethoxysulfuron, halosulfuron-methyl, metamitron and a control without application. The evaluations were: control, phytointoxication and plant height at 7, 14 and 21 DAA; stem diameter, leaf area, dry mass of aerial part and roots at 21 DAA. The results showed that herbicides ethoxysulfuron ( 60 and $80 \mathrm{~g} \mathrm{ha}^{-1}$ ), halosulfuron-methyl (75 and $112.5 \mathrm{~g}$ ha $\left.{ }^{1}\right)$ and metamitron $\left(2,800\right.$ and $\left.4,200 \mathrm{~g} \mathrm{ha}^{-1}\right)$ were selective to castor. Ethoxysulfuron (60 and $\left.80 \mathrm{~g} \mathrm{ha}^{-1}\right)$ and halosulfuron-methyl (75 and $112.5 \mathrm{~g} \mathrm{ha}^{-1}$ ) were effective for the volunteer soybean control.
\end{abstract}

Keywords: Glycine max, Ricinus communis, management, tolerance, weed.

Abbreviations: ALS_acetolactate synthase; CEC_cation-exchange capacity; DAA_days after application; OM_organic matter; Protox_protoporphyrinogen oxidase.

\section{Introduction}

The oil extracted from castor seeds is used in the chemical industry for a number of products (Severino et al., 2015). However, world consumption has been limited by insufficient production, with an economic potential for the expansion of castor cultivation (Campbell et al., 2014).

In this context, the crop has aroused interests as an alternative of second crop to soybean in areas of grain production, such as Brazilian Savanna (Rocha et al., 2016). Consequently, concerns about the need to control plants resulting from remaining soybean seeds (called volunteers), have increased because they can compete for water, light and nutrients with crops sown in succession (Silva and Concenço, 2014; Sá et al., 2015). Despite this, research in weed management of castor crop has been neglected and are scarce (Severino et al., 2012; Costa et al., 2014) and the lack of information is substantially higher regarding the control of volunteer species such as soybean.

The only registered herbicide for the castor in Brazil is Saflufenacil, with a recommendation for application in directed application between the lines of the crop (Brasil,
2017). Brighenti (2015) found that Saflufenacil is not effective for the control of volunteer soybean. In this context, limitations may exist in finding herbicides to control dicotyldons, while simultaneously being selective to castor. Some herbicides are used for controlling castor in other crops (Vitorino et al., 2012). In general, castor is highly susceptible to the broadleaf herbicides.

The studies about this issue have indicated several compounds as non-selective to castor: acifluorfen, imazapic, imazethapyr, lactofen, 2,4-DB (Grichar et al., 2012), diuron, atrazine, atrazine + simazine, atrazine + metolachlor, diclosulan, 2,4-D, flumetsulan, imazaquin, imazapyr, sulfentrazone, isoxaflutole and pyrithiobac-sodium (Costa et al., 2014). The results have indicated only chlorimurom-ethyl as selective latifolicide to castor in post-emergence (Maciel et al., 2006; Sofiatti et al., 2012), but because it is selective and recommended for soybean crop, does not represent control this species (Brasil, 2017).

Assis et al. (2014) reported the control of soybean plants with ethoxysulfuron at 3 trefoil stage. Costa et al. (2015) 
observed that herbicides with action mechanism of ALS inhibition, such as ethoxysulfuron and halosulfuron-methyl, contributed to the control of Richardia scabra in the castor crop, indicating the possibility of further studies involving these and other active ingredients for the control of dicotyledon species. Thus, the objective of this work was to evaluate the selectivity and efficacy of post-emergent herbicides for the control of volunteer soybean in the castor crop.

\section{Results and Discussion}

\section{Selectivity of post-emergent herbicides to the castor crop}

In all phases of evaluation, severe phytotoxification was verified in the castor with iodosulfuron-methyl, ioxynil and oxadiazon, with percentages between 72 and $88 \%$ (Table 1). Exception occurred for iodosulforun-methyl at $3.5 \mathrm{~g} \mathrm{ha}^{-1}$ in the first evaluation (7 DAA), with $29 \%$ phytotoxification. No significant effect was observed to control soybean using ethoxysulfuron, halosulfuron-methyl and metamitron, because the phytotoxication rates were mild or moderate, with values between 4 and $20 \%$.

A review of weed management in the castor crop (Costa et al., 2014) revealed that herbicides with mechanisms of enzyme Protox inhibition, such as oxadiazon in the present study, are not selective to this crop. However, for herbicides that inhibit photosystem II, some variation may occur, with occurrence of mild or even severe phytotoxification, as verified with metamitron and ioxynil, respectively. Similar situation can be verified for active ingredients with ALS inhibition action, as can be observed from the higher percentages of phytotoxification obtained with iodosulfuronmethyl and less with halosulfuron-methyl and ethoxysulfuron.

It was possible to verify growth reduction and plant height with application of ioxynil, oxadiazon and iodosulfuronmethyl (5 $\mathrm{g} \mathrm{ha}^{-1}$ ) at 14 and 21 DAA, whose values corresponded, on average, to $25 \%$ decrease compared to the control (Table 1). No significant effect was observed on height at all times after applicaton of iodosulfuron-methyl at the lowest dose $\left(3.5 \mathrm{~g} \mathrm{ha}^{-1}\right)$, ethoxysulfuron, halosulfuronmethyl and metamitron.

The iodosulfuron-methyl, ioxynil and oxadiazon herbicides interfered with the growth of stem diameter, leaf area and root and shoot mass accumulation in both evaluated doses of each active ingredient (Table 2). The mean reductions of stem diameter, leaf area and root and shoot mass accumulation were $32,81,79$ and $74 \%$, respectively, compared to control. Similar to that occurred by phytointoxication and plant height, ethoxysulfuron, halosulfuron-methyl and metamitron did not cause significant decrease in stem diameter, leaf area and dry mass of roots and shoot.

Costa et al. (2012) verified a mild phytotoxification (18\%) by ethoxysulfuron, with a dose of $60 \mathrm{~g} \mathrm{ha}^{-1}$. However, they observed a reduction in the growth of the castor when the herbicide was applied at $150 \mathrm{~g} \mathrm{ha}^{-1}$. Silva et al. (2010) did not observe interferences on stem diameter, height and leaf area of the castor after post-emergence application of halosulfuron-methyl (13.5 to $112.5 \mathrm{~g} \mathrm{ha}^{-1}$ ). Silva et al. (2015) did not observe interferences on the same growth characteristics by application for desiccation with halosulfuron-methyl herbicide at $112.5 \mathrm{~g} \mathrm{ha}^{-1}$, applied just before sowing the castor.

In a work of selectivity and efficacy of herbicides, Costa et al. (2015) verified mild phytointoxication symptoms when chlorimuron-ethyl was applied between 4 to 6 true leaves of castor, followed by halosulfuron-methyl (112.5 $\mathrm{g} \mathrm{ha}^{-1}$ ) or ethoxysulfuron ( 60 or $120 \mathrm{~g} \mathrm{ha}^{-1}$ ). Besides, they did not find interference on the diameter of the stem and height of the plants at harvest time. In this study, the treatment with halosulfuron-methyl resulted in similar yield compared to control without herbicide application.

Thus, considering the previous studies and the information obtained, it is verified that halosulfuron-methyl is confirmed as selective herbicide for castor. In the present study, Ethoxysulfuron, especially at lower doses, also presented potential use for the crop, mainly because it caused slight symptoms of phytotoxification and did not interfere in any of the growth characteristics. In a similar way, it is important to highlight the tolerance of the castor to the metamitron. It might be a new possibility of latifolicide in post-emergence. It also appeared to be an alternative for new studies in preemergency applications, as it is also recommended for this modality of application (Brazil, 2017), for which there are no selective herbicides with predominant action on eudicots to castor.

\section{Volunteer soybean control with post-emergence herbicides}

In all control evaluations, it was possible to observe effects of the herbicides on soybean plants (Table 3). At 7 DAA, the herbicide actions and respective doses were similar, with percentages varying between 67 and $76 \%$. At 14 and 21 DAA, there was an intensification of the control caused by ethoxysulfuron and halosulfuron-methyl, with percentages varying between 99 and 100\%, which corresponded respectively to excellent control and plant death. However, for metamitron the values remained lower, between 67 and $74 \%$, corresponding to bad or weak control levels.

York et al. (2005) found effective control of volunteer soybeans in cotton with trifloxysulfurom-sodium. This herbicide, as well as ethoxysulfuron and halosulfuronmethyl, belongs to the chemical group of sulfonylureas, whose mechanism of action is the inhibition of the ALS enzyme (Oliveira Jr, 2011), however, it is not considered selective to castor (Ferreira et al., 2009).

Assis et al. (2014) verified the death of soybean plants with the $36 \mathrm{~g} \mathrm{ha}^{-1}$ of ethoxysulfuron in mixture with $0.5 \%\left(\mathrm{v} \mathrm{v}^{-1}\right)$ mineral oil applied in V3. However, the results were below $80 \%$ when the adjuvant was not used. Considering these results, smaller doses than those used in the present study may also control volunteer soybeans. However, they may require the addition of mineral oil to the application solution and, consequently, increase the risk of phytointoxication to castor.

Other post-emergent herbicides have been reported to be effective in controlling volunteer soybeans such as diquat, paraquat, paraquat + diuron, 2,4-D, atrazine (Dan et al., 2009 and 2011; Lima et al., 2011 and Silva and Concenço, 2014), ametryn and glufosinate-ammonium (Brighenti, 2015). However, for the castor there are studies indicating only viability of 2,4-D associated with glyphosate in the desiccation prior to sowing and paraquat + diquat in a 
Table 1. Effect of treatments on phytointoxication and height of castor plants.

\begin{tabular}{|c|c|c|c|c|}
\hline \multirow{2}{*}{ Treatments } & \multirow{2}{*}{$\begin{array}{l}\text { Doses } \\
\left(\mathrm{g} \mathrm{ha}^{-1}\right)\end{array}$} & \multicolumn{3}{|c|}{ Phytointoxication (\%) } \\
\hline & & $7 \mathrm{DAA}$ & $14 \mathrm{DAA}$ & $21 \mathrm{DAA}$ \\
\hline Ethoxysulfuron & 60.0 & $5.3 \mathrm{~d}$ & $4.5 \mathrm{~b}$ & $5.8 \mathrm{~b}$ \\
\hline Ethoxysulfuron & 80.0 & $11.0 \mathrm{~d}$ & $10.8 \mathrm{~b}$ & $17.0 \mathrm{~b}$ \\
\hline Halosulfuron-methyl & 75.0 & $6.0 \mathrm{~d}$ & $4.0 \mathrm{~b}$ & $10.5 \mathrm{~b}$ \\
\hline Halosulfuron-methyl & 112.5 & $5.0 \mathrm{~d}$ & $4.3 \mathrm{~b}$ & $5.3 \mathrm{~b}$ \\
\hline lodosulfuron-methyl & 3.5 & $29.3 \mathrm{~cd}$ & $72.3 \mathrm{a}$ & $73.8 \mathrm{a}$ \\
\hline lodosulfuron-methyl & 5.0 & $53.8 \mathrm{bc}$ & 80.0 a & $80.8 \mathrm{a}$ \\
\hline Ioxynil & 355.0 & $78.8 \mathrm{ab}$ & $81.5 \mathrm{a}$ & $69.0 \mathrm{a}$ \\
\hline Ioxynil & 710.0 & $87.3 \mathrm{a}$ & 88.0 a & $81.3 \mathrm{a}$ \\
\hline Metamitron & 2800.0 & $15.5 \mathrm{~d}$ & $20.3 b$ & $19.5 \mathrm{~b}$ \\
\hline Metamitron & 4200.0 & $4.8 \mathrm{~d}$ & $6.3 \mathrm{~b}$ & $9.5 \mathrm{~b}$ \\
\hline Oxadiazon & 750.0 & $71.8 \mathrm{ab}$ & $82.0 \mathrm{a}$ & $75.0 \mathrm{a}$ \\
\hline Oxadiazon & 1000.0 & $80.0 \mathrm{ab}$ & $85.8 \mathrm{a}$ & $78.8 \mathrm{a}$ \\
\hline Control & 0.0 & $0.0 \mathrm{~d}$ & $0.0 \mathrm{~b}$ & $0.0 \mathrm{~b}$ \\
\hline $\mathrm{F}$ & - & $32.6^{*}$ & 53.9* & $28.6 *$ \\
\hline CV (\%) & - & 34.9 & 25.6 & 32.5 \\
\hline \multirow{2}{*}{ Treatments } & Doses & \multicolumn{3}{|c|}{ Height (cm) } \\
\hline & $\left(\mathrm{g} \mathrm{ha}^{-1}\right)$ & $7 \mathrm{DAA}$ & $14 \mathrm{DAA}$ & $21 \mathrm{DAA}$ \\
\hline Ethoxysulfuron & 60.0 & 29.1 & $43.5 \mathrm{a}$ & $47.3 \mathrm{ab}$ \\
\hline Ethoxysulfuron & 80.0 & 30.2 & $42.0 \mathrm{a}$ & $45.0 \mathrm{abc}$ \\
\hline Halosulfuron-methyl & 75.0 & 30.1 & $44.1 \mathrm{a}$ & $47.5 \mathrm{ab}$ \\
\hline Halosulfuron-methyl & 112.5 & 31.7 & 43.9 a & $46.8 \mathrm{ab}$ \\
\hline lodosulfuron-methyl & 3.5 & 23.9 & $25.3 b$ & $26.8 \mathrm{~cd}$ \\
\hline lodosulfuron-methyl & 5.0 & 24.4 & $25.4 \mathrm{~b}$ & $25.3 d$ \\
\hline Ioxynil & 355.0 & 29.3 & $33.1 \mathrm{ab}$ & $36.8 \mathrm{abcd}$ \\
\hline Ioxynil & 710.0 & 24.9 & $25.1 b$ & $24.8 d$ \\
\hline Metamitron & 2800.0 & 27.4 & $38.1 \mathrm{ab}$ & $41.8 \mathrm{abcd}$ \\
\hline Metamitron & 4200.0 & 31.0 & $45.0 \mathrm{a}$ & $49.0 \mathrm{a}$ \\
\hline Oxadiazon & 750.0 & 22.8 & $25.1 \mathrm{~b}$ & $29.3 \mathrm{bcd}$ \\
\hline Oxadiazon & 1000.0 & 23.4 & $22.9 \mathrm{~b}$ & $26.3 \mathrm{~cd}$ \\
\hline Control & 0.0 & 30.3 & $48.1 \mathrm{a}$ & $52.8 \mathrm{a}$ \\
\hline $\mathrm{F}$ & - & $2.3^{\mathrm{NS}}$ & $9.1^{*}$ & $7.7^{*}$ \\
\hline CV (\%) & - & 15.6 & 17.9 & 19.8 \\
\hline
\end{tabular}

Means followed by the same letter in the column does not differ significantly from each other by Tukey test $(p \leq 0.05) .{ }^{*}$ Significant at $5 \%$ of probability; ${ }^{\mathrm{NS}}$ not significant.

Table 2. Effect of treatments on stem diameter (SD), leaf area (LA), dry mass of roots (DMR) and aerial part (DMAP) of castor plants.

\begin{tabular}{|c|c|c|c|c|c|}
\hline Treatments & $\begin{array}{l}\text { Doses } \\
\left(\mathrm{g} \mathrm{ha}^{-1}\right)\end{array}$ & $\begin{array}{l}\text { SD } \\
(\mathrm{mm})\end{array}$ & $\begin{array}{l}\mathrm{LA} \\
\left(\mathrm{cm}^{2}\right)\end{array}$ & $\begin{array}{l}\text { DMR } \\
\text { (g) }\end{array}$ & $\begin{array}{l}\text { DMAP } \\
\text { (g) }\end{array}$ \\
\hline Ethoxysulfuron & 60.0 & $4.2 \mathrm{abcd}$ & $1998.2 \mathrm{a}$ & $3.2 \mathrm{ab}$ & $14.5 \mathrm{a}$ \\
\hline Ethoxysulfuron & 80.0 & $4.3 \mathrm{abcd}$ & 1730.6 a & $3.1 \mathrm{ab}$ & $16.0 \mathrm{a}$ \\
\hline Halosulfuron-methyl & 75.0 & $4.6 \mathrm{abc}$ & $2128.5 \mathrm{a}$ & $4.0 \mathrm{a}$ & $15.2 \mathrm{a}$ \\
\hline Halosulfuron-methyl & 112.5 & $4.8 \mathrm{ab}$ & $1961.4 \mathrm{a}$ & $3.6 \mathrm{a}$ & $16.2 \mathrm{a}$ \\
\hline lodosulfuron-methyl & 3.5 & $3.7 \mathrm{bcd}$ & $457.6 \mathrm{~b}$ & $1.0 \mathrm{bc}$ & $6.2 \mathrm{bc}$ \\
\hline lodosulfuron-methyl & 5.0 & $3.5 \mathrm{~cd}$ & $149.4 \mathrm{~b}$ & $0.7 \mathrm{c}$ & $4.0 \mathrm{c}$ \\
\hline loxynil & 355.0 & $3.7 \mathrm{bcd}$ & $686.3 \mathrm{~b}$ & $0.9 \mathrm{bc}$ & $4.5 c$ \\
\hline loxynil & 710.0 & $3.2 \mathrm{~d}$ & $378.1 \mathrm{~b}$ & $0.6 \mathrm{c}$ & $3.6 \mathrm{c}$ \\
\hline Metamitron & 2800.0 & $4.2 \mathrm{abcd}$ & $1778.1 \mathrm{a}$ & $2.6 \mathrm{abc}$ & $12.0 \mathrm{ab}$ \\
\hline Metamitron & 4200.0 & $4.7 \mathrm{ab}$ & 2040.8 a & $3.2 \mathrm{ab}$ & $16.0 \mathrm{a}$ \\
\hline Oxadiazon & 750.0 & $3.4 \mathrm{~d}$ & $628.5 \mathrm{~b}$ & $0.9 \mathrm{bc}$ & $4.9 \mathrm{bc}$ \\
\hline Oxadiazon & 1000.0 & $3.3 \mathrm{~d}$ & $486.6 \mathrm{~b}$ & $0.6 \mathrm{c}$ & $4.6 \mathrm{c}$ \\
\hline Control & 0.0 & $5.1 \mathrm{a}$ & $2439.0 \mathrm{a}$ & $3.7 \mathrm{a}$ & 17.6 a \\
\hline $\mathrm{F}$ & - & $7.6^{*}$ & $16.7^{*}$ & $8.5^{*}$ & $15.4^{*}$ \\
\hline CV (\%) & - & 11.5 & 31.3 & 43.3 & 28.1 \\
\hline
\end{tabular}


Table 3. Effect of treatments on control and height of soybean plants.

\begin{tabular}{|c|c|c|c|c|}
\hline \multirow[b]{2}{*}{ Treatments } & \multirow{2}{*}{$\begin{array}{l}\text { Doses } \\
\left(\mathrm{g} \mathrm{ha}^{-1}\right)\end{array}$} & \multicolumn{3}{|c|}{ Control (\%) } \\
\hline & & $7 \mathrm{DAA}$ & $14 \mathrm{DAA}$ & $21 \mathrm{DAA}$ \\
\hline Ethoxysulfuron & 60.0 & $75.3 \mathrm{a}$ & $99.0 \mathrm{a}$ & $100.0 \mathrm{a}$ \\
\hline Ethoxysulfuron & 80.0 & $75.8 \mathrm{a}$ & $98.8 \mathrm{a}$ & 99.3 a \\
\hline Halosulfuron-methyl & 75.0 & $78.3 \mathrm{a}$ & $99.0 \mathrm{a}$ & $99.5 \mathrm{a}$ \\
\hline Halosulfuron-methyl & 112.5 & $83.8 \mathrm{a}$ & $99.3 \mathrm{a}$ & $99.5 \mathrm{a}$ \\
\hline Metamitron & 2800.0 & $69.5 \mathrm{a}$ & $66.5 \mathrm{~b}$ & $67.3 b$ \\
\hline Metamitron & 4200.0 & $67.5 \mathrm{a}$ & $72.8 b$ & $73.5 b$ \\
\hline Control & 0.0 & $0.0 \mathrm{~b}$ & $0.0 \mathrm{c}$ & $0.0 \mathrm{c}$ \\
\hline $\mathrm{F}$ & - & $59.8 *$ & $57.2^{*}$ & $58.2^{*}$ \\
\hline $\mathrm{CV}(\%)$ & - & 11.6 & 12.6 & 12.5 \\
\hline \multirow{2}{*}{ Treatments } & Doses & \multicolumn{3}{|c|}{ Height $(\mathrm{cm})$} \\
\hline & $\left(\mathrm{g} \mathrm{ha}^{-1}\right)$ & $7 \mathrm{DAA}$ & $14 \mathrm{DAA}$ & $21 \mathrm{DAA}$ \\
\hline Ethoxysulfuron & 60.0 & $17.3 \mathrm{c}$ & $14.8 \mathrm{c}$ & $11.5 \mathrm{~b}$ \\
\hline Ethoxysulfuron & 80.0 & $18.6 \mathrm{bc}$ & $15.0 \mathrm{c}$ & $12.9 \mathrm{~b}$ \\
\hline Halosulfuron-methyl & 75.0 & $18.8 \mathrm{bc}$ & $14.8 \mathrm{c}$ & $3.0 \mathrm{~b}$ \\
\hline Halosulfuron-methyl & 112.5 & $19.0 \mathrm{bc}$ & $15.3 \mathrm{c}$ & $10.4 \mathrm{~b}$ \\
\hline Metamitron & 2800.0 & $21.5 a b$ & $25.8 \mathrm{ab}$ & $26.4 \mathrm{a}$ \\
\hline Metamitron & 4200.0 & $19.3 \mathrm{bc}$ & $23.6 \mathrm{~b}$ & $27.6 \mathrm{a}$ \\
\hline Control & 0.0 & $22.5 \mathrm{a}$ & $29.1 \mathrm{a}$ & 33.9 a \\
\hline $\mathrm{F}$ & - & $6.9^{*}$ & $68.9^{*}$ & $22.6^{*}$ \\
\hline CV (\%) & - & 7.0 & 7.6 & 26.5 \\
\hline
\end{tabular}

Table 4. Effect of treatments on stem diameter (SD), leaf area (LA), dry mass of roots (DMR) and aerial part (DMAP) of soybean plants.

\begin{tabular}{llllll}
\hline Treatments & $\begin{array}{l}\text { Doses } \\
\left(\mathrm{g} \mathrm{ha}^{-1}\right)\end{array}$ & $\begin{array}{l}\text { SD } \\
(\mathrm{mm})\end{array}$ & $\begin{array}{l}\text { LA } \\
\left(\mathrm{cm}^{2}\right)\end{array}$ & $\begin{array}{l}\text { DMR } \\
(\mathrm{g})\end{array}$ & $\begin{array}{l}\text { DMAP } \\
(\mathrm{g})\end{array}$ \\
\hline Ethoxysulfuron & 60.0 & $1.9 \mathrm{bc}$ & $0.0 \mathrm{c}$ & $25.3 \mathrm{~b}$ & $174.0 \mathrm{c}$ \\
Ethoxysulfuron & 80.0 & $1.7 \mathrm{bc}$ & $0.0 \mathrm{c}$ & $26.3 \mathrm{~b}$ & $199.5 \mathrm{c}$ \\
Halosulfuron-methyl & 75.0 & $1.1 \mathrm{c}$ & $0.0 \mathrm{c}$ & $31.8 \mathrm{~b}$ & $182.5 \mathrm{c}$ \\
Halosulfuron-methyl & 112.5 & $1.1 \mathrm{c}$ & $0.0 \mathrm{c}$ & $41.3 \mathrm{~b}$ & $175.0 \mathrm{c}$ \\
Metamitron & 2800.0 & $2.8 \mathrm{ab}$ & $261.3 \mathrm{~b}$ & $87.0 \mathrm{ab}$ & $437.0 \mathrm{~b}$ \\
Metamitron & 4200.0 & $2.7 \mathrm{ab}$ & $167.5 \mathrm{bc}$ & $44.0 \mathrm{~b}$ & $296.5 \mathrm{bc}$ \\
Control & 0.0 & $3.2 \mathrm{a}$ & $671.8 \mathrm{a}$ & $109.5 \mathrm{a}$ & $848.5 \mathrm{a}$ \\
\hline $\mathrm{F}$ & - & $9.9^{*}$ & $30.9^{*}$ & $5.9^{*}$ & $25.2^{*}$ \\
$\mathrm{CV}(\%)$ & - & 26.0 & 57.1 & 51.7 & 29.9 \\
\hline Means followed by the same letter in the column does not differ significantly from each other by Tukey test (p $\leq 0.05)$. * Significant at 5\% of probability; ${ }^{\text {N5 }}$ not significant.
\end{tabular}

Direct application between the crop lines (Maciel et al., 2008; Costa et al., 2014).

For height of soybean plants, treatments with ethoxysulfuron and halosulfuron-methyl promoted the reductions in all epochs of evaluation (Table 3). The mean percentages of growth reduction corresponded to 18,49 and $72 \%$ at 7,14 and 21 DAA, respectively, compared to the control. Only the highest dose of metamitron, $\left(4,200 \mathrm{~g} \mathrm{ha}^{-1}\right)$ at 14 DAA resulted in interference with soybean plant height with a lower effect than other herbicides.

Similar to the effect on height, ethoxysulfuron and halosulfuron-methyl herbicides caused the greatest growth reductions for other evaluated characteristics (Table 4). The mean percentages of decrease in relation to the control corresponded to: $55 \%$ for stem diameter, $100 \%$ for leaf area, $71 \%$ for root and $72 \%$ for aerial part dry mass. The metamitron at the dose of $4,200 \mathrm{~g} \mathrm{ha}^{-1}$, did not make any difference on leaf area, root and aerial part dry mass, compared to the effect of ethoxysulfuron and halosulfuronmethyl.

Therefore, the herbicides ethoxysulfuron (75 and $112.5 \mathrm{~g}$ $\mathrm{ha}^{-1}$ ) and halosulfuron-methyl ( 60 and $80 \mathrm{~g} \mathrm{ha}^{-1}$ ) were shown to be the most effective control options for volunteer soybean at V3 stage. It is also worth to mention that if these herbicides are used in the castor crop, they may be options for the control of glyphosate-resistant soybean, whose cultivation is predominant in Brazil (Rizzardi and Silva, 2014; ISAAA, 2016).

\section{Materials and Methods}

\section{Plant materials, experimental design and conduction}

Two experiments were conducted under greenhouse conditions, located at coordinates $7^{\circ} 13^{\prime} 20^{\prime \prime} \mathrm{S}$, and $35^{\circ} 54^{\prime}$ $14^{\prime \prime} \mathrm{W}$. The first assay was focused on the selectivity of herbicides to the castor crop, and the second to evaluate efficacy of herbicides for soybean control, conducted from September to November 2015 and May 2016 to July 2016, respectively.

In order to compose the substrate in both trials, we used a soil from the arable layer $(0$ to $20 \mathrm{~cm}$ ) of fallow agricultural area (7 17' 29" S e 39o 15' 59" W), classified as Fluvisol (Embrapa, 2013), sandy-clay-sand, whose chemical characteristics were: $\mathrm{pH}$ in water $=6.7 ; \mathrm{Ca}^{+2}=149.7 \mathrm{mmol}_{\mathrm{c}}$ $\mathrm{dm}^{-3} ; \mathrm{Mg}^{+2}=69.1 \mathrm{mmol}_{\mathrm{c}} \mathrm{dm}^{-3} ; \mathrm{Na}^{+}=1.2 \mathrm{mmol}_{\mathrm{c}} \mathrm{dm}^{-3} ; \mathrm{K}^{+}=6.2$ 
$\mathrm{mmol}_{\mathrm{c}} \mathrm{dm}^{-3} ; \mathrm{S}=226.2 \mathrm{mmol}_{\mathrm{c}} \mathrm{dm}^{-3} ; \mathrm{H}+\mathrm{Al}=49.5 \mathrm{mmol}_{\mathrm{c}} \mathrm{dm}^{-3} ;$ $\mathrm{CEC}=275.7 \mathrm{mmol}_{\mathrm{c}} \mathrm{dm}^{-3} ; \mathrm{V}=82.0 \% ; \mathrm{Al}^{+3}=0.03 \mathrm{mmol}_{\mathrm{c}} \mathrm{dm}^{-3}$; $\mathrm{P}=9.4 \mathrm{mg} \mathrm{dm}^{-3}$ and $\mathrm{OM}=23.5 \mathrm{~g} \mathrm{~kg}^{-1}$. Subsequently, the soil was sieved in a $2 \mathrm{~mm}$ mesh, dried in the shade, fertilized with $3 \mathrm{~kg} \mathrm{~m}^{-3}$ of monoammonium phosphate. In the first experiment, the substrate was composed only of the fertilized soil, and in the second in a mixture of three equal parts in volume, composed of soil fertilized, sand and organic fertilizer composed of decomposed vegetable residue, commercialized for seedlings production. In both experiments, the substrates were used to fill $5 \mathrm{~L}$ plastic vessels, constituting the experimental plots.

The tests were installed in a completely randomized design with four replicates. The cultivars BRS Energia (castor) and BRS 8280RR (soybean) were sown in the first and second experiments, at $3 \mathrm{~cm}$ depth and twelve seeds per pot, and the thinning was carried out seven days after the emergence of the seedlings, from which one plant was maintained per container. To maintain humidity, daily irrigation was carried out using a system composed of micro sprinklers with preprogrammed operation.

\section{Treatments}

In the first experiment, to evaluate the efficacy of selectivity of post-emergent herbicides to castor, the treatments were constituted by: ethoxysulfuron ( $\left.60 \mathrm{~g} \mathrm{ha}^{-1}\right)$; ethoxysulfuron (80 $\left.\mathrm{g} \mathrm{ha}^{-1}\right)$; halosulfuron-methyl (75 $\mathrm{g} \mathrm{ha}^{-1}$ ); halosulfuronmethyl (112.5 $\left.\mathrm{g} \mathrm{ha}^{-1}\right)$; iodosulfuron-methyl (3.5 $\left.\mathrm{g} \mathrm{ha}^{-1}\right)$; iodosulfuron-methyl $\left(5 \mathrm{~g} \mathrm{ha}^{-1}\right)$; ioxynil $\left(355 \mathrm{~g} \mathrm{ha}^{-1}\right)$; ioxynil (710 $\left.\mathrm{g} \mathrm{ha}^{-1}\right)$; metamitron $\left(2,800 \mathrm{~g} \mathrm{ha}^{-1}\right)$; metamitron $(4,200 \mathrm{~g}$ $\left.\mathrm{ha}^{-1}\right)$; oxadiazon (750 $\left.\mathrm{g} \mathrm{ha}^{-1}\right)$; oxadiazon $\left(1,000 \mathrm{~g} \mathrm{ha}^{-1}\right)$ and one control without application. In the second assay, treatments to evaluate soybean control were selected based on the results obtained in the first experiment: ethoxysulfuron (60 $\left.\mathrm{g} \mathrm{ha}^{-1}\right)$; ethoxysulfuron (80 $\left.\mathrm{g} \mathrm{ha}^{-1}\right)$; halosulfuron-methyl (75 $\mathrm{g} \mathrm{ha}^{-1}$ ); halosulfuron-methyl (112.5 $\left.\mathrm{g} \mathrm{ha}^{-1}\right)$; metamitron $\left(2,800 \mathrm{~g} \mathrm{ha}^{-1}\right)$; metamitron $\left(4,200 \mathrm{~g} \mathrm{ha}^{-1}\right)$ and one control without application.

\section{Herbicide applications}

The applications were carried out as post-emergence, in the stages of 4 and 6 true leaves of the castor and the third open soybean trefoil (V3). A backpack sprayer with $\mathrm{CO}_{2}$ constant pressure was used. It was equipped with a boom containing four XR 11002 flat fan nozzles, spaced $0.5 \mathrm{~m}$ apart and positioned at $0.5 \mathrm{~m}$ height of the target, constituting consumption of $200 \mathrm{~L} \mathrm{ha}^{-1}$. In the application solutions, noni poly (ethyleneoxy) ethanol compound ( $200 \mathrm{~g} \mathrm{~L}^{-1}$ commercial product) was added with concentration of $0.5 \%\left(v v^{-1}\right)$ for halosulfuron-methyl and $0.3 \%$ for metamitron and iodosulfuron-methyl, according to general recommendations for their use (Brasil, 2017). The wind speed, temperature and relative humidity data were recorded at the beginning and at the end of the applications by a digital thermo-hygrometer, whose averages corresponded respectively to: $1 \mathrm{~m} \mathrm{~s}^{-1}, 27^{\circ} \mathrm{C}$ and $63 \%$ in the first experiment and at $0.4 \mathrm{~m} \mathrm{~s}^{-1}, 25.1{ }^{\circ} \mathrm{C}$ and $70.2 \%$ in the second experiment.

\section{Traits measured}

At 7, 14 and 21 days after application (DAA), the height of the plants of both species was evaluated. The height was measured from the soil surface until the insertion of the apical bud. The phytointoxication of castor and soybean was measured by means of visual scales of percentage notes (SBCPD, 1995), where $0 \%$ meant no damage and $100 \%$ the death of the plants. At 21 DAA, stem diameter, leaf area, dry shoot biomass and root system were evaluated in both plants and trials. The diameter of the castor and soybean stems was measured close to the soil surface using a digital caliper. The leaf area was obtained by estimation from the leaf dimensions of castor and leaflets of soybean plants, according to Severino et al. (2004) and Richter et al. (2014), respectively. The dry shoot biomass and roots of the plants were obtained by drying the plant material in a forced air ventilation oven at $65^{\circ} \mathrm{C}$ and for a period of 72 hours until reaching a constant mass and then weighing it in a semianalytical balance.

\section{Statistical analysis}

The data were subjected to analysis of variance and the means were compared by the Tukey test at 0.05 probability.

\section{Conclusion}

The herbicides ethoxysulfuron (60 and $\left.80 \mathrm{~g} \mathrm{ha}^{-1}\right)$, halosulfuron-methyl ( 75 and $112.5 \mathrm{~g} \mathrm{ha}^{-1}$ ) and metamitron $\left(2,800\right.$ and $\left.4,200 \mathrm{~g} \mathrm{ha}^{-1}\right)$ applied at the 4 to 6 leaf stage were selective to castor (BRS Energia). Ethoxysulfuron (60 and $80 \mathrm{~g}$ $\mathrm{ha}^{-1}$ ) and halosulfuron-methyl (75 and $112.5 \mathrm{~g} \mathrm{ha}^{-1}$ ) applied in the V3 stage were effective to the control the volunteer soybean (BRS $8280 R R$ ).

\section{Acknowledgments}

The authors thank CNPq [Conselho Nacional de Desenvolvimento Científico e Tecnológico (National Counsel of Technological and Scientific Development)] by the scholarship provided for the first author.

\section{References}

Assis ACLP, Reis MR, Pessoa GDO, Silva DV, Hayata M, Dias RC, Rocha BH (2014) Seletividade do ethoxysulfuron às culturas da soja e feijão. Rev Bras Herb. 13:117-124.

Brasil (2017) Agrofit- sistemas de agrotóxicos fitossanitários. Available

at: http://extranet.agricultura.gov.br/agrofit_cons/principal_a grofit_cons. Accessed in: August 2017.

Brighenti AM (2015) Control of volunteer soybean plants in sunflower crop. Pesq Agropec Trop. 45:274-281.

Campbell DN, Rowland DL, Schnell RW, Ferrell JA, Wilkie AC (2014) Developing a castor (Ricinus communis L.) production system in Florida, US: evaluating crop phenology and response to management. Ind Crop Prod. 53:221-227. 
Costa AGF, Sofiatti V, Maciel CDG, Lira AJS, Cordeiro Jr AF, Silva RLM (2015) Weed management with herbicides applied in pre and postemergence on castor crop. Planta Daninha. 33:551-559.

Costa AGF, Sofiatti V, Maciel CDG, Poletine JP, Sousa JI (2014) Weed management strategies for castor bean crops. Acta Sci-Agron. 36:135-145.

Costa AGF, Sofiatti V, Silva DRDS (2012) Seletividade de herbicidas pós-emergentes à mamoneira para o controle de ciperáceas. Paper presented at the 5 th Congresso Brasileiro de Mamona and 2nd Simpósio Internacional de Oleaginosas e Energéticas, Embrapa Algodão, Guarapari, 16-19 June 2012.

Dan HA, Barroso ALL, Procópio SO, Dan LGM, Neto AMO, Guerra N, Braz GBP (2009) Controle químico de plantas voluntárias de soja Roundup Ready . Rev Bras Herb. 8:96101.

Dan HA, Procópio SO, Barroso ALL, Dan LGM, Neto AMO, Guerra N (2011) Controle de plantas voluntárias de soja com herbicidas utilizados em milho. Agrária. 6:253-257.

Empresa Brasileira de Pesquisa Agropecuária - Embrapa (2013) Sistema brasileiro de classificação de solos, 3rd edn. Embrapa, Brasília. 353 p.

Ferreira UCQ, Queiroz WN, Beltrão NEM (2009) Fitotoxicidade e seletividade do herbicida trifloxysulfuron sodium na mamona cultivar BRS Nordestina. Rev Bras Eng Agr Amb. 13:916-921.

Grichar WJ, Dotray PA, Trostle CL (2012) Castor (Ricinus communis L.) tolerance to postemergence herbicides and weed control efficacy. Int J Agron. 2012:1-5.

International Service for the Acquisition of Agri-biotech Applications - ISAAA (2016). Global status of commercialized biotech/GM crops: 2016. Available at: http://www.isaaa.org/resources/publications/briefs/52/do wnload/isaaa-brief-52-2016.pdf. Accessed in: August 2017.

Lima DBC, Silva AG, Procópio SO, Barroso ALL, Dan HA (2011) Controle químico de plantas voluntárias de soja Roundup Ready ${ }^{\oplus}$ em diferentes estádios de desenvolvimento. Rev Caatinga. 24:64-70.

Maciel CDG, Poletine JP, Velini ED, Amaral JGC, Zani LP, Santos RF, Rodrigues M, Raimondi MA, Ribeiro RB (2008) Possibilidade de aplicação de misturas de herbicidas de ação total com jato dirigido em mamoneira de porte anão. Planta Daninha. 26:457-464.

Maciel CDG, Ribeiro RB, Poletine JP, Velini ED, Zanoto MD, Rosa EL, Rodrigues M, Raimondi MA (2006) Seletividade do herbicida chlorimuron-ethyl (Chlorimuron Master Nortox ${ }^{\circ}$ ) para cultivares de mamoneira em diferentes estádios de desenvolvimento. Paper presented at the 25th Congresso Brasileiro da Ciência das Plantas Daninhas, SBCPD/UNB/Embrapa Cerrados, Brasília, 29 May-12 June 2006.

Oliveira Jr RS (2011) Mecanismo de ação de herbicidas. In: Oliveira Jr RS, Constantin J, Inoue $\mathrm{MH}$ (ed). Biologia e manejo de plantas daninhas. 1st edn. Omnipax, Curitiba, 7.
Richter GL, Júnior AZ, Streck NA, Guedes JVC, Kraulich B, Rocha TSM, Winck JEM, Cera JC (2014) Estimativa de área de folhas de cultivares antigas e modernas de soja por método não destrutivo. Bragantia. 73:416-425.

Rizzardi MA, Silva L (2014) Manejo de plantas daninhas eudicotiledôneas na cultura da soja Roundup Ready". Planta Daninha. 32:683-697.

Rocha VS, Costa AGF, Trovão DMBM, Zonta JH, Sofiatti V, Maciel CDG, Almeida HAS (2016) Management of volunteer castor bean in the glyphosate-resistant soybean crop. Planta Daninha. 34:545-553.

Sá RO, Galbieri R, Bélot J, Zanotto MD, Dutra SG, Severino LS, Silva CJ (2015) Mamona: opção para rotação de cultura visando a redução de nematoides de galha no cultivo do algodoeiro. Available at: https://ainfo.cnptia.embrapa.br/digital/bitstream/item/12 4092/1/circular-tecnica-edicao15-bx.pdf. Accessed in: October 2017.

Severino LS, Auld DL, Baldanzi M, Cândido MJD, Chen G, Crosby W, Tan D, Xiaohua H, Lakshmamma P, Lavanya C, Machado OLT, Mielke T, Milani M, Miller TD, Morris JB, Morse SA, Navas AA, Soares D, Sofiatti V, Wang ML, Zanotto MD, Zieler $H$ (2012) A review on the challenges for increased production of castor. Agron J. 104:853-880.

Severino LS, Cardoso GD, Vale LS, Santos JW (2004) Método para determinação da área foliar da mamoneira. Rev Bras Ol Fibros. 8:753-762.

Severino LS, Mendes BSS, Lima GS (2015) Seed coat specific weight and endosperm composition define the oil content of castor seed. Ind Crop Prod. 75:14-19.

Silva AF, Concenço G (2014) Manejo de tigueras na sucessão soja RR - Milho RR. Rev Plantio Direto. 140:2-6.

Silva RLM, Costa AGF, Sofiatti V, Ribeiro VV, Maciel CDG, Monteiro DR (2015). Seletividade do halosulfuron-methyl aplicado em pré-emergência da cultura da mamoneira. Rev Bras Eng Agr Amb. 19:693-697.

Silva VNB, Silva FMO, Sofiatti V, Silva KC, Silva DM (2010) Tolerância da cultura da mamoneira ao herbicida halosulfuron. Paper presented at the 4th Congresso Brasileiro de Mamona and 1st Simpósio Internacional de Oleaginosas e Energéticas, Embrapa Algodão, João Pessoa, 7-10 June 2010.

Sociedade Brasileira da Ciência das Plantas Daninhas SBCPD (1995) Procedimentos para instalação, avaliação e análise de experimentos com herbicidas. SBCPD, Londrina. $42 \mathrm{p}$.

Sofiatti V, Severino LS, Silva FMO, Silva VNB, Brito GG (2012) Pre and post emergence herbicides for weed control in castor crop. Ind Crop Prod. 37:235-237.

Vitorino HS, Martins D, Costa SIA, Marques RP, Souza GSF, Campos CF (2012) Eficiência de herbicidas no controle de plantas daninhas em mamona. Arq Inst Biol. 79:127-131.

York AC, Beam JB, Culpepper AS (2005) Control of volunteer glyphosate-resistant soybean in cotton. J Cotton Sci. 9:102109. 